\title{
管通し平板ガセット形式接合部を有する軸力材の弾性座屈挙動 \\ ELASTIC BUCKLING BEHAVIOR OF AXIALLY COMPRESSED TUBE WITH THROUGH-GUSSET CONNECTION
}

\author{
多田元 英*, 西豊**, 井上一朗*** \\ Motohide TADA, Yutaka NISHI and Kazuo INOUE
}

\begin{abstract}
Through-gusset connection is often used for axially compressed tube member. Buckling modes are the bending of whole member and the bending in the region of the connection. Mechanical model corresponding to each buckling mode is established. Using these models, elastic buckling loads are analytically derived. The buckling behavior is examined for the members having a variety of proportion. It is obtained that the member having long connection-region buckles in the connectionregion and the corresponding buckling load can be smaller than the Euler's load of the pin-ended tube. The analytical results are confirmed in comparison with the results of loading tests.
\end{abstract}

Keywords : elastic stability, buckling load, axially compressed member, tube, through-gusset type connection 弾性安定，座屈荷重，軸力材，鋼管，管通しガセット形式接合部

\section{1. 序}

筋かいやトラス構成部材などの軸力材に鋼管を用いる場合, 図 1 のような管通しガセット形式の接合方法がよく探用される．圧縮力 に対する 2 種類の可能な座屈モードを図中に示す，座屈モードA は 部材全体にわたる座屈であり，モードBは接合部領域だけの部分的 な座屈である．「ガセットプレート部」「添板部」「鋼管部」の各 部断面のプロポーションによっては座届モードB が生じ，その座屈 荷重が端部ピンの銅管のオイラー座屈荷重を下回る可能性も十分に 考えられる。

本論では，座屈モード A, B に対応する簡便な力学モデルを設定 し，それぞれの弾性座屈荷重を，文献 1)を参考にして導き，各部の プロポーションと座屈モード・座屈荷重の関係を考察する．さら に，ここで提案する弾性座屈荷重算定式の妥当性を，円形䤡管を用 いた座届実験により険証する。

管通しガセットプレート継手に関する既往の研究には，継手部分 の耐力を扱ったもの 2) 4)が多い. 部材の座届性状を扱ったものとし ては鈴木 ·小河らの研究5)が挙げられるが, 長さが短い漸形形状の 金具を銅管に割り込んだ接合部を対象にしているため，接合部領域 だけの部分的な座屈は考慮の対象外となっている。

\section{2. 座届モードAに対する弾性座屈荷重}

図 1 に示すような接合部を有する軸力材を，曲げ剛性の相違に応 じて三領域に分割して考え，それぞれを次のように定議する，すな わち,

ガセットプレート部：ガセットプレートだけが面外の曲け畘性に奇 与する領域で，材端から添板の第 1 ボルトまでの区間，および䤡管 端部から添板の第 1 ボルトまでの区間とする.

添板部：ガセットブレートと添板の合成断面が面外の曲げ㓝性に奇

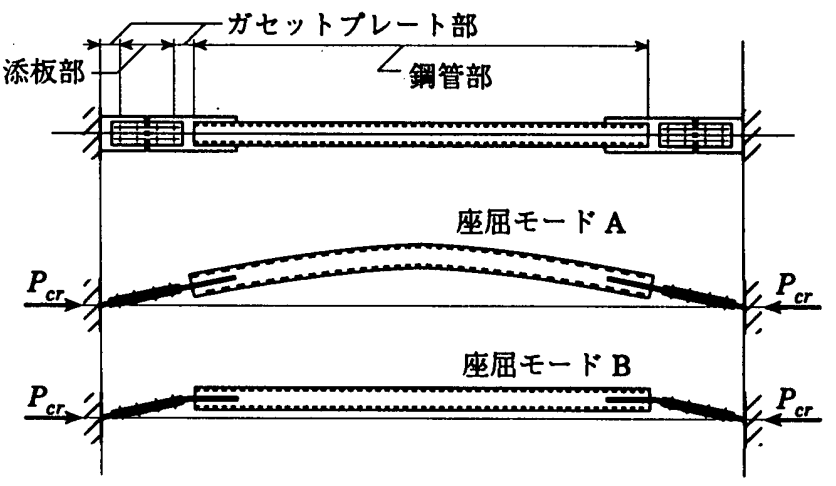

図1管通しガセット形式の接合部と座屈モード

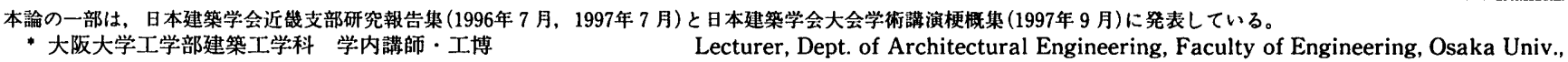

** 大阪大学工学部建築工学科 大学院生

****阪大学工学部建築工学科 助教授 $\cdot$ 工博 Dr. Eng.

Graduate Student, Dept. of Architectural Engineering, Faculty of Engineering, Osaka Univ.

Assoc. Prof., Dept. of Architectural Engineering, Faculty of Engineering, Osaka Univ., Dr. Eng.
} 
与する領域で，添板の両第 1 ボルト間の区間とする．本論では，各 板間のずれ变形を無視して添板部の曲げ剛性を算定している。

金管部：铜管が位置する区間とする。

座屈モードA に対する力学モデルとしては, 図 2 に示すように, 添板部を無視して材端のガセットプレート部を回転バネにモデル化 し，銅管の断面二次モーメント $I_{t b}$ をもつ弾性棒に中間部をモデル 化する．添板部の曲げ剛性は鋼管部よりも一般に小さいため,この モデル化は座屈荷重を高めに評価する：しかし，添板部の剛性が非 常に小さかったり同部の長さが非常に長い場合には座屈モードは B に移行する．したがって，座屈モードがA となる簳囲では過大評価 の程度は小さいと判断し，このようなモデルを設定している．この 過大評価の程度は，5章で実験結果と比較して考察する．材端バネ の回転剛性 ${ }_{A} K_{1}$ は，図 3 を参考にして次式で近似する。

$$
A^{K_{1}}=\frac{E I_{g s}}{k_{a} k_{b} l}
$$

ただし， $I_{g s}$ : ガセットプレート部の断面二次モーメント， $E$ : ヤン グ係数， $l$ : 軸力材全長である， $k_{a}, k_{b}$ は，図 2 に示すように各部 の長さの比率を規定する無次元量である，一方，バネの位置はガ セットプレート部の中央とする. したがって, モデルの材長 $l_{1}$ は次 式となる.

$$
l_{1}=\left(1-k_{a} k_{b}\right) l
$$

対称性より，図4のように軸力材の半分を切り出して考える. 部 材軸方向に $x$ 軸をとり，たわみを $y$ とし軸方向荷重を $P$ とすれば, 弾性棒部分の釣合方程式が次式で与えられる。

$$
\frac{d^{2}}{d x^{2}}\left(E I_{t b} \frac{d^{2} y}{d x^{2}}\right)+P \frac{d^{2} y}{d x^{2}}=0
$$

一般解は，樻分定数を $C_{1}, C_{2}, C_{3}, C_{4}$ として次のようになる.

$$
y=C_{1} \sin (\alpha x)+C_{2} \cos (\alpha x)+C_{3} x+C_{4}
$$

ただし，

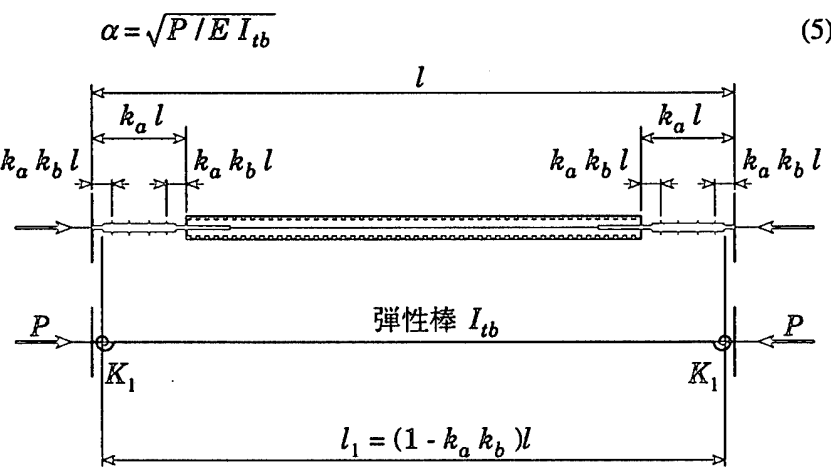

图 2 弾性棒一回転バネモデル

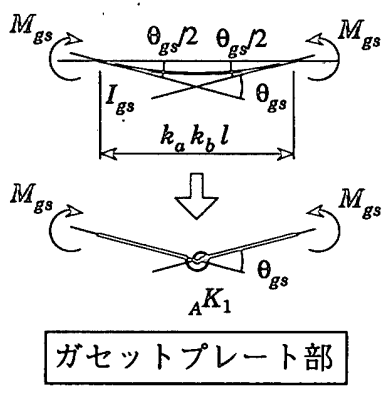

图 3 材端ガセットプレート部 のモデル化

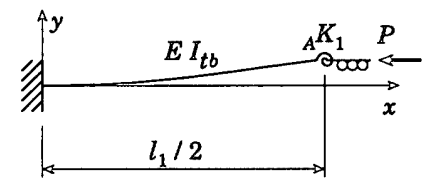

圆 4 部材半分のモデル
境界条件を以下に示す。

$$
\begin{aligned}
& \left.y\right|_{x=0}=0,\left.\quad \frac{d y}{d x}\right|_{x=0}=0 \\
& \left.E I_{t b} \frac{d^{3} y}{d x^{3}}\right|_{x=l_{1} / 2}+\left.P \frac{d y}{d x}\right|_{x=l_{1} / 2}=0 \\
& \left.E I_{t b} \frac{d^{2} y}{d x^{2}}\right|_{x=l_{1} / 2}+\left.{ }_{A} K_{1} \frac{d y}{d x}\right|_{x=l_{1} / 2}=0
\end{aligned}
$$

(8) 式は弾性棒材端の材軸と直交方向の釣合条件, (9) 式は弾性棒の 材端曲げモーメントがバネの曲げモーメントに等しいという条件を 表している．（4)を(6)～(9) 式に代入して次式を得る.

$$
\begin{aligned}
& C_{2}+C_{4}=0, \quad C_{1} \alpha+C_{3}=0, \quad C_{3}=0 \\
& \left\{-C_{1} \alpha^{2} \sin \left(\alpha l_{1} / 2\right)-C_{2} \alpha^{2} \cos \left(\alpha l_{1} / 2\right)\right\} \\
& +\beta^{2}\left\{C_{1} \alpha \cos \left(\alpha l_{1} / 2\right)-C_{2} \alpha \sin \left(\alpha l_{1} / 2\right)+C_{3}\right\}=0
\end{aligned}
$$
ただし，

$$
\beta=\sqrt{A^{K_{1}} / E I_{t b}}
$$

(11),(12) 式より $C_{1}=C_{3}=0$ を得，これらを(13) 式に代入して次式 を得る。

$$
C_{2}\left\{\alpha+\beta^{2} \tan \left(\alpha l_{1} / 2\right)\right\}=0
$$

上式において， $C_{2}=0$ のときは(10)式より $C_{4}=0$ となり， $C_{1}=C_{2}$ $=C_{3}=C_{4}=0$ の自明な解となる. 自明でない解を得るには上式の 括弧内がゼロでなければならない.すなわち,

$$
\tan \left(\alpha l_{1} / 2\right)=-\alpha / \beta^{2}
$$

(1)，(2),(14) 式を用いれば，(16) 式は次のように書き改められる.

ただし，

$$
\tan \left(\alpha l_{1} / 2\right)=\frac{-k_{a} k_{b} \alpha l_{1}}{\bar{I}_{g s}\left(1-k_{a} k_{b}\right)}
$$

$$
\bar{I}_{g s}=I_{g s} / I_{t b}
$$

この方程式の解は, 次の二つの関数の交点として図 5 のように求め ることができる。

$$
\begin{gathered}
f=\tan \left(\alpha l_{1} / 2\right) \\
f=\frac{-2 k_{a} k_{b}}{\bar{I}_{g s}\left(1-k_{a} k_{b}\right)}\left(\alpha l_{1} / 2\right) \\
\text { このようにして求められた解を } x \text { とおく. すなわち, } \\
\alpha l_{1} / 2=x
\end{gathered}
$$

(21)に (2), (5) 式を代入しPについて解けば，モードAによる弾性 座屈荷重 ${ }_{A} P_{c r}$ が次のように得られる.

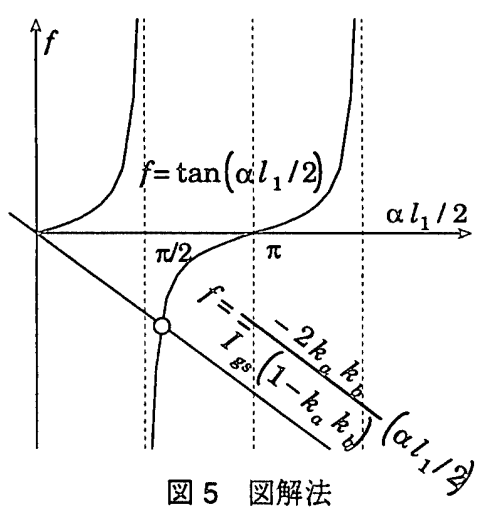




$$
{ }_{A} P_{c r}=P_{e}\left\{\frac{2 x}{\pi\left(1-k_{a} k_{b}\right)}\right\}^{2}
$$

ただし， $P_{e}$ は両端ピンで長さlの鋼管のオイラー座屈荷重であり， 次式で表せる.

$$
P_{e}=\pi^{2} E I_{t b} / l^{2}
$$

一方，(22) 式の両辺を鋼管の断面積 $A_{t b}$ で除せば，座屈開始時の鋼 管断面の平均応力度 ${ }_{t b}{ }^{A} \sigma_{c r}$ が次のように与えられる.

ただし，

$$
{ }_{t b}^{A} \sigma_{c r}=\frac{E}{\lambda^{2}}\left(\frac{2 x}{1-k_{a} k_{b}}\right)^{2}
$$

$$
\lambda=l / \sqrt{I_{t b} / A_{t b}}
$$

ガセットプレートの幅を $b_{g s}$ ，厚さを $t_{g s}$ とし， (18), (23) 式の関係 を用いれば，(22)式は次のように書き改められる。

$$
{ }_{A} P_{c r}=\frac{E b_{g s} t_{g s}{ }^{3}}{3 l^{2} \bar{I}_{g s}}\left(\frac{x}{1-k_{a} k_{b}}\right)^{2}
$$

(26) 式の両辺をガセットプレートの断面積 $b_{g s} t_{g s}$ で除せは；座屈 開始時のガセットプレート断面の平均応力度 ${ }_{g s}{ }^{A} \sigma_{c r}$ が, 接合部の長 さ $k_{a} l$ と板厚 $t_{g s}$ との比 $\left(k_{a} l / t_{g s}\right)$ の関数として次のように得られ る.

$$
{ }_{g s}^{A} \sigma_{c r}=\frac{E}{3\left(k_{a} l / t_{g s}\right)^{2} \bar{I}_{g s}}\left(\frac{k_{a} x}{1-k_{a} k_{b}}\right)^{2}
$$

\section{3. 座屈モードBに対する弾性座屈荷重}

座屈モード B は，図1に示すように左右の接合部領域だけが屈 曲するモードである，図 1 には左右が対称に同一方向に屈曲する モードを示しているが，左右が逆対称に $\mathrm{S}$ 字状に変形するモードも 運動学的には許容される。しかしこのような S 字状モードが 2 次 の座屈モードになることを別途に確認したので，ここでは左右が対 称に変形するモードだけを扱う。

図1に示すように，軸力材を「「ガセットプレート部」・「添板 部」・「鋼管部」に分割して考える. 図3に示すようにガセットプ レート部を二本の剛棒と一つの回転バネにモデル化し，図6に示す ように添板部と鋼管部を一本の剛棒と二つの端部回転バネにモデル 化する．図１に示すような座屈モード B では，ガセットプレート
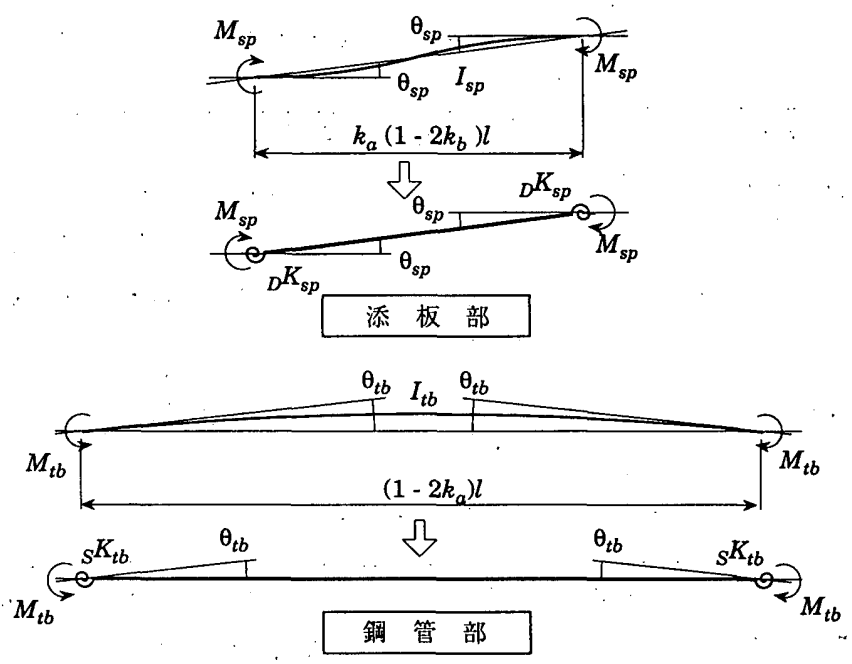

图 6 各部の剛棒一回転バネモデル
部と鋼管部は単曲率，添板部は複曲率の曲げを受ける，各部内の曲 げモーメントを対称曲げと逆対称曲げに近似すれば， $K_{g s}$ (ガセッ トプレート中央部回転バネの曲け剛性）， ${ }_{D} K_{s p}$ (巡対称曲げを受け る添板端部回転バネの曲げ剛性）， ${ }_{s} K_{t b}$ （対称曲げを受ける鋼管端 部回転バネの曲け剛性）は，図6を参考にして次のように与えられ る.

$$
K_{g s}=\bar{K}_{g s} E I_{t b} / l,{ }_{D} K_{s p}={ }_{D} \bar{K}_{s p} E I_{t b} / l,{ }_{s} K_{t b}={ }_{s} \bar{K}_{t b} E I_{t b} / l l
$$
ただし，

$$
\begin{aligned}
& \bar{K}_{g s}=\frac{\bar{I}_{g s}}{k_{a} k_{b}},{ }_{D} \bar{K}_{s p}=\frac{6 \bar{I}_{s p}}{k_{a}\left(1-2 k_{b}\right)},{ }_{s} \bar{K}_{t b}=\frac{2}{1-2 k_{a}} \\
& \cdots \cdots(29 \mathrm{a}),(29 \mathrm{~b}),(29 \mathrm{c}) \\
& \bar{I}_{s p}=I_{s p} / I_{t b} \\
& I_{s p}: \text { 添板部の断面二次モーメント }
\end{aligned}
$$

「ガセットプレート部」・「添板部」・「鋼管部」はそれぞれ直 列に接続されており，また「ガセット.プレート部」が他の領域と比 較して一般に短いことから，各部をモデル化した回転バネを「ガ セットプレート部」のバネ位置に直列に集約して考えることにす る.すなわち，“軸力材全体の剛棒一回転バネモデルを図7のように 設定し，図中に示す回転バネの曲げ剛性 ${ }_{B} K_{1},{ }_{B} K_{2}$ を，これらに接 続する各部の回転バネを直列に組み合わせて次式のように与える.

$$
{ }_{B} K_{1}={ }_{B} \bar{K}_{1} E I_{t b} / l,{ }_{B} K_{2}={ }_{B} \bar{K}_{2} E \dot{I}_{t b} / l
$$
ただし，

$$
\begin{aligned}
& { }_{B} \bar{K}_{1}=\frac{1}{1 / \bar{K}_{g s}+1 /{ }_{D} \bar{K}_{s p}} \\
& { }_{B} \bar{K}_{2}=\frac{!}{1 / \bar{K}_{g s}+1 /{ }_{D} \bar{K}_{s p}+1 /{ }_{s} \bar{K}_{t b}}
\end{aligned} .
$$

対応する座屈モードを図 8 に示す：端部が $\theta$ 回転したときの力の 釣合条件は，図 9 を参照して次のように与えられる。

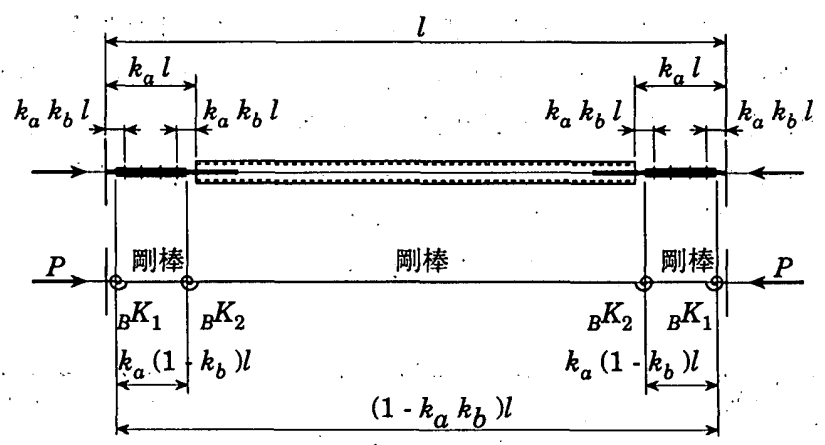

図77. 軸力材全体の剛棒一回転バネモデル

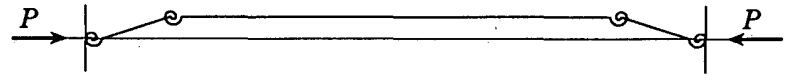

图 8 剛棒一回転バネモデルの座屈モード

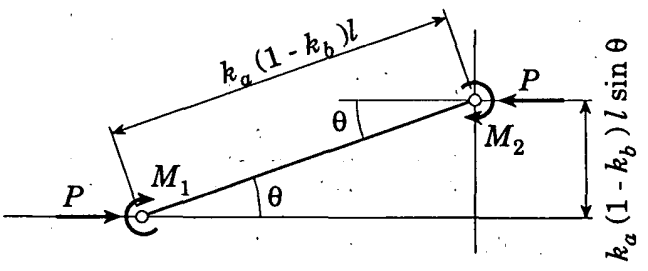

図 9 端部変形時の力の釣合 


$$
P=\frac{1}{k_{a}\left(1-k_{b}\right) l \sin \theta}\left(M_{1}+M_{2}\right)
$$

ここで， $M_{1}, M_{2}$ は回䎐バネの曲げモーメントであり，次式で与え られる。

$$
M_{1}={ }_{B} \bar{K}_{1} \frac{E I_{t b}}{l} \theta, M_{2}={ }_{B} \bar{K}_{2} \frac{E I_{t b}}{l} \theta
$$

(23), (34)を用いて (33) 式を次のように寒竟改蚂る。

$$
P \pi^{2} k_{a}\left(1-k_{b}\right) \sin \theta=\left({ }_{B} \bar{K}_{1}+{ }_{B} \bar{K}_{2}\right) P_{c} \theta
$$

微小变位を仮定すれば住1) $\sin \theta \doteqdot \theta$ であり，(35)式は次のように 留亭改められる。

$$
P \pi^{2} k_{a}\left(1-k_{b}\right) \theta=\left({ }_{B} \bar{K}_{1}+{ }_{B} \bar{K}_{2}\right) P_{e} \theta
$$

$P$ が次式の ${ }_{B} P_{c r}$ を满足すれば任意の $\theta$ に対して上式が成立する. すなわち，材端接合部がモードBを伴って不安定となる荷重 ${ }_{B} P_{c r}$ は 次式で与えられることになる.

$$
{ }_{B} P_{c r}=P_{e} \frac{{ }_{B} \bar{K}_{1}+{ }_{B} \bar{K}_{2}}{\pi^{2} k_{a}\left(1-k_{b}\right)}
$$

(24), (27) 式の誇導と同様にして, 座屈開始時の溉管断面の平均応力

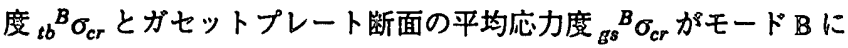
封して次のように与えられる。

$$
\begin{aligned}
& { }_{b b}^{B} \sigma_{c r}=\frac{E}{\lambda^{2}} \frac{{ }_{B} \bar{K}_{1}+{ }_{B} \bar{K}_{2}}{k_{a}\left(1-k_{b}\right)} \\
& \underset{g_{s}}{B} \sigma_{c r}=\frac{E}{12\left(k_{a} l / t_{B^{s}}\right)^{2} \bar{I}_{g^{g}}} \frac{k_{a}\left(\bar{K}_{1}+{ }_{B} \bar{K}_{2}\right)}{1-k_{b}}
\end{aligned}
$$

\section{Q. 弾性庭属渏重と庭屈モード}

2,3 章で得られた弾性座屈荷重を図 10 に示す、縦朝は端部ピン の銅管のオイラー座屈荷重 $\left(\boldsymbol{P}_{e}\right)$ で無次元化している．横朝は，接合 部長さの部材長に対する比 $\left(k_{a}\right)$ である．パラダータの標準值を $k_{b}$ $=0.1, \bar{I}_{B^{s}}=0.007, \bar{I}_{s p}=0.06$ とし，これらの值の組合せを記号 $(\mathbb{M})$ で表す. $\bar{I}_{g s}, \bar{I}_{s p}$ の設定根拠は付録に示す。きた，座屈荷重が大き くなるように各パラォータの值を標準值の倍または半分にした組合 せを記号 (L)で表し，逆に座屈荷重が小さくなるように各パラメー タの值を同榜に変化させた組合せを記号 (\$) で表す。これらのパラ メータの組合せを表 1 に整理して示す.

图 10 より， $k_{a}$ が小さい範囲では座屈モードは $\mathrm{A}$ となり， $k_{a}$ が
大妾い飾囲では $\mathrm{B}$ となることがわかる，座屈モード $\mathrm{A}$ と B の境界 はここで設定したパラメータの範囲では $k_{a}=0.05 \sim 0.15$ 程度で ある．また，座屈荷重が端部ピンの銅管のオイラー座屈荷重を下回 るのは， $\ell_{a}=0.05 \sim 0.2$ 侱度を超えるときである.

銅管断面の弾性座屈開始時平均応力度を図 11 (a) ( (c) に示す。（a) ，(b) 図はそれぞれ座届モードA，B に対応したものであり，(c) 図 は，支配的な座屈モードに対する関係を示している、いずれも，

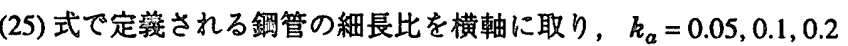

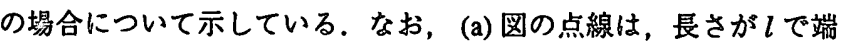
部がピンの鋼管のオイラー座届応力度を示しており，(23) 式を鋼管 の断面积 $\left(A_{t b}\right)$ で除した閔數を示している。

(a) 図において，モードAに対応する座屈時平均応力度が，銅管 のオイラー座屈応力度を若干上回っている。これは, 部材端の固定 度が多少なりとも期待できることによる，(b) 図では，座屈モード $\mathrm{B}$ に对応する銅管断面の座屈時平均応力度が, $k_{a}$ の変化に伴って 大きく変化している.

ガセットプレート断面の座屈開始時平均応力度を図 12 (a) ( c) に 竄 1 パラメータの設定値

\begin{tabular}{|c|c|c|c|}
\hline & $(\mathrm{L})$ & $(\mathbb{M})$ & $(\mathrm{S})$ \\
\hline$k_{b}$ & 0.05 & 0.10 & 0.20 \\
\hline $\bar{I}_{g s}$ & 0.014 & 0.007 & 0.0035 \\
\hline $\bar{I}_{s p}$ & 0.12 & 0.06 & 0.03 \\
\hline
\end{tabular}

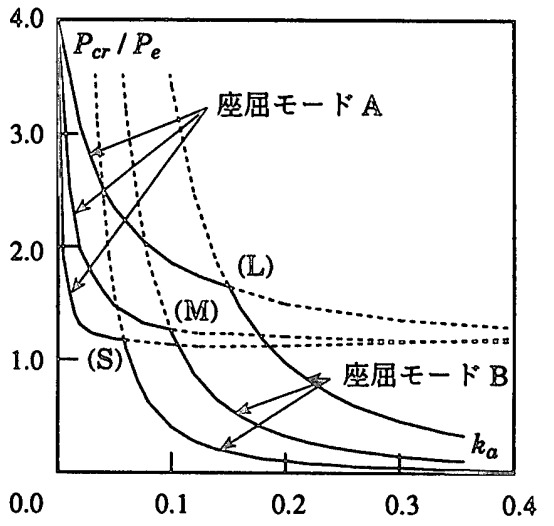

図 40 弾性座屈荷重と座屈モード

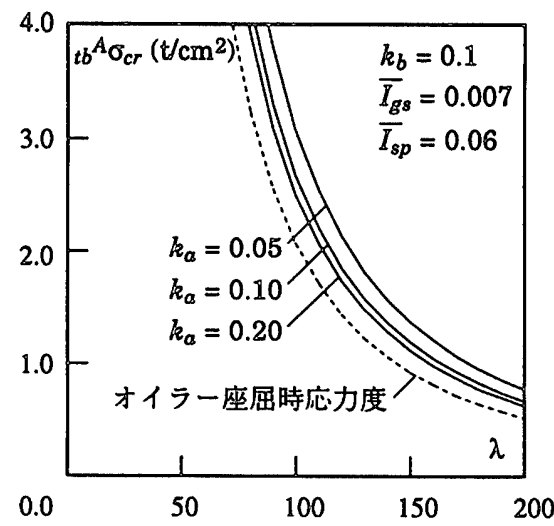

(a) 座屈そードA

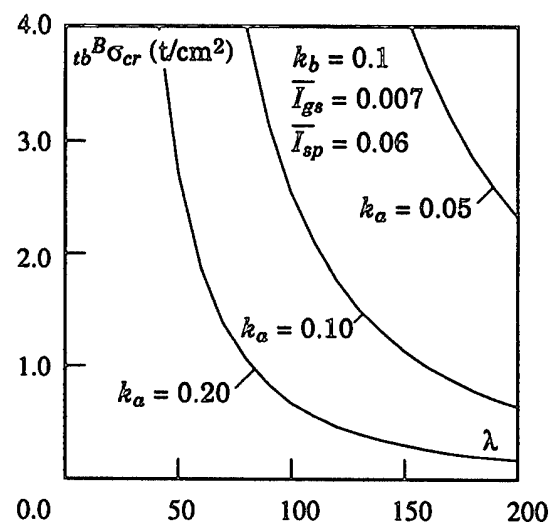

(b) 邀屈そード8

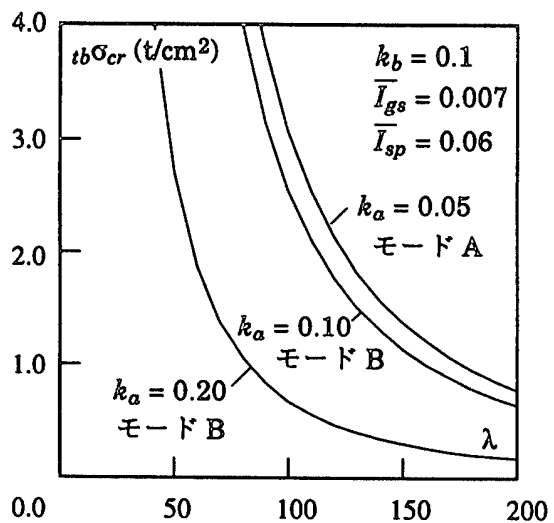

(c) 支配的なモード

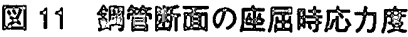




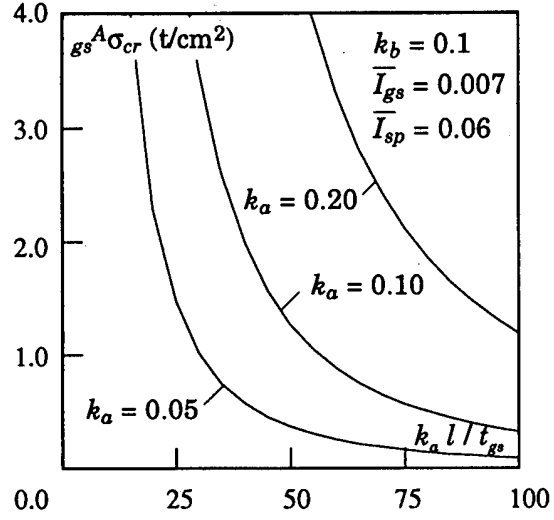

(a) 座屈モードA

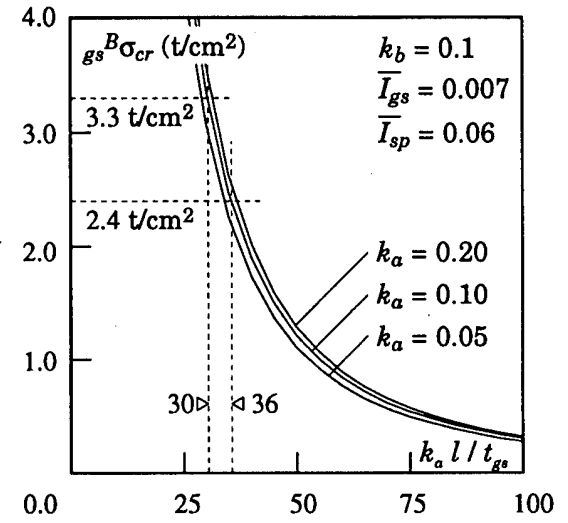

(b) 座屈モードB

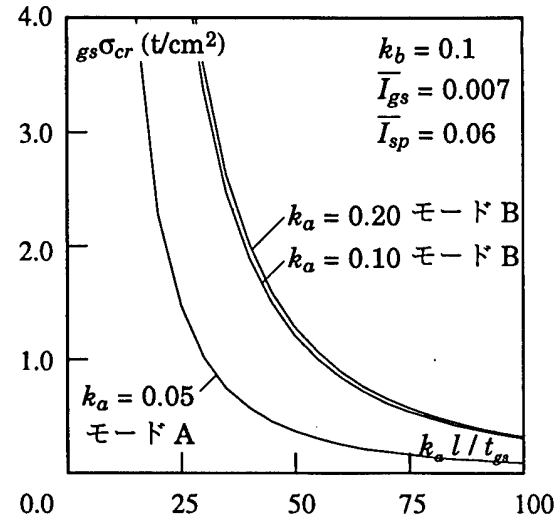

(c) 支配的なモード

図 12 ガセットプレート断面の座屈時応力度

示す. 図 11 と同様に，(a), (b) 図はそれぞれ座屈モード A, B に対 応したものであり，(c) 図は, 支配的な座屈モードに対する関係を 示している。横軸は, 接合部の長さとガセットプレート厚との比 ( $\left.k_{a} l / t_{g s}\right)$ である. (b) 図より, SN400では $k_{a} l / t_{g s}<36$ 程度, $\mathrm{SN} 490$ では $k_{a} l / t_{g s}<30$ 程度であれば，モード B の弾性座屈より もガセットプレート断面が先に降伏することがわかる.

\section{5. 円形鋼管を用いた弾性座屈実験結果との比較}

\section{1 実験概要と試験体}

図 13 に実験概要を示す.ガセットプレートは材軸方向に幅を一 定とし，F10T·M20の高力ボルトによる二面摩擦接合で組み立て る、試験体両端のガセットプレートをリブ付きプレートで挟み込 み, 面内外の回転を拘束する. 鋼管には明瞭な降伏点と降伏棚を有 する機械構造用炭素鋼鋼管（STKM13A）を用い，全試験体とも同 じ断面とする.

試験体の一覧を図 14 と表 2 に示し，断面の実測值と材料の降伏 応力度を表 3 に示す． 降伏応力度は $0.2 \%$ オフセッット值で定義して いる. 実験変数は, 摩擦接合部のボルト列数であり, 接合部領域の 材長に対する比 $\left(k_{a}\right)$ を 0.076 から 0.268 まで変化させている，なお， 各変数につき試験体数を 2 としている.

\section{2 実験結果と計算結果の比較}

2,3 章で提案した簡便な力学モデルを用いて計算した各試験体の
弾性座屈荷重を図 15 に示す．縋軸は，両端ピンの鋼管のオイラー 座屈荷重 $\left(P_{e}\right)$ で無次元化した弾性座屈荷重であり, 横軸は $k_{a}$ であ る. 水平線が座屈モード $\mathrm{A}$ に対応する座屈荷重であり，右下がりの 曲線は座屈モードB に対応する座屈荷重である，4章の図 10 では, 座屈モード A に対応する座屈荷重が右下がりの曲線となっているの に対し，図 15 では水平線となっている．これは，図10の解析では $k_{b}$ を一定に保って $k_{a}$ を変化させたのに対し，ここでは $k_{a} k_{b}$ の積 を一定に保って $k_{a}$ を変化させたため, 表 2 に示すように $k_{a}$ の変化 に伴って $k_{b}$ も変化することによる，なお，鋼管やガセットプレー トの降伏軸力の $P_{e}$ に対する比は，それぞれ 2.19 と2.71であり, 弾 性座屈荷重を上回っている.

図中に実験結果を○・○でプロットする，のの黒登り印はモード A，○の白抜き印はモードB で座屈したことを示す．簡便な力学モ デルによる計算結果と実験結果は座屈モードが一致している，座屈 荷重は，実験結果が計算結果よりも若干小さくなっている，両者の 乘離は，モード A・B の境界付近の $2 \mathrm{H} 25$ で最も大きく，これより $k_{a}$ が大または小の方向に離れるにしたがい乘離が小さくなってい る.これは，2 章で述べたように，モードAの力学モデルにおい て，部材全長にわたって鋼管の断面二次モーメントを用いているこ と，およびモード A · B の境界付近での実変形は各モード成分が混 在しているのに対し，簡便力学モデルではどちらか一方の变形モー ドに変形を拘束していることなどが原因として挙げられる.

実験終了後の座屈变形を写真 1 (a), (b) に示す. 写真 (a) はモード
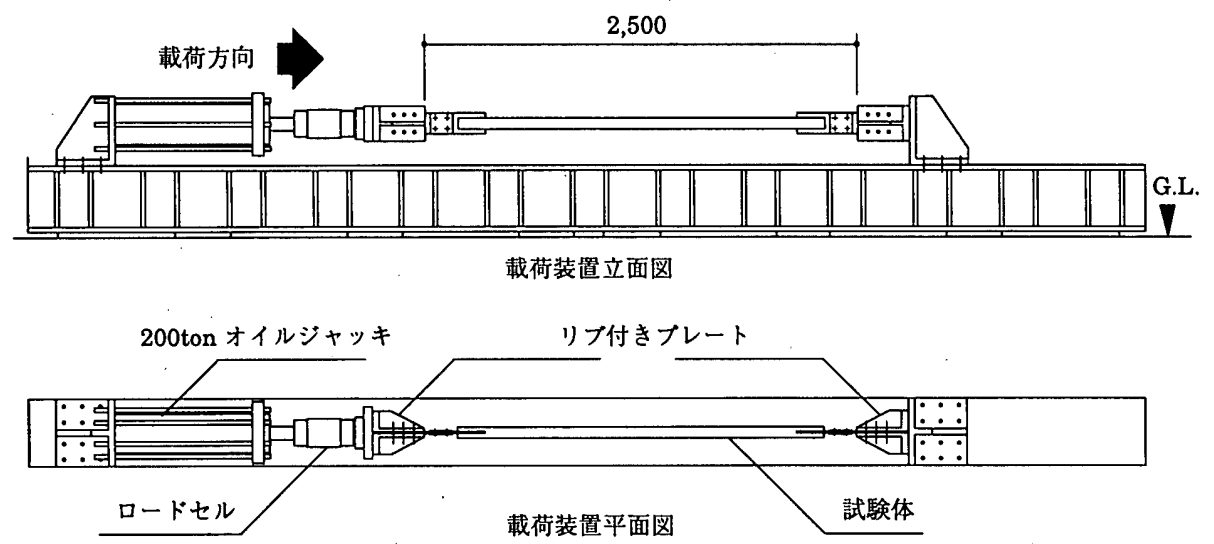

図 13 数值解析結果と評価値の比較 


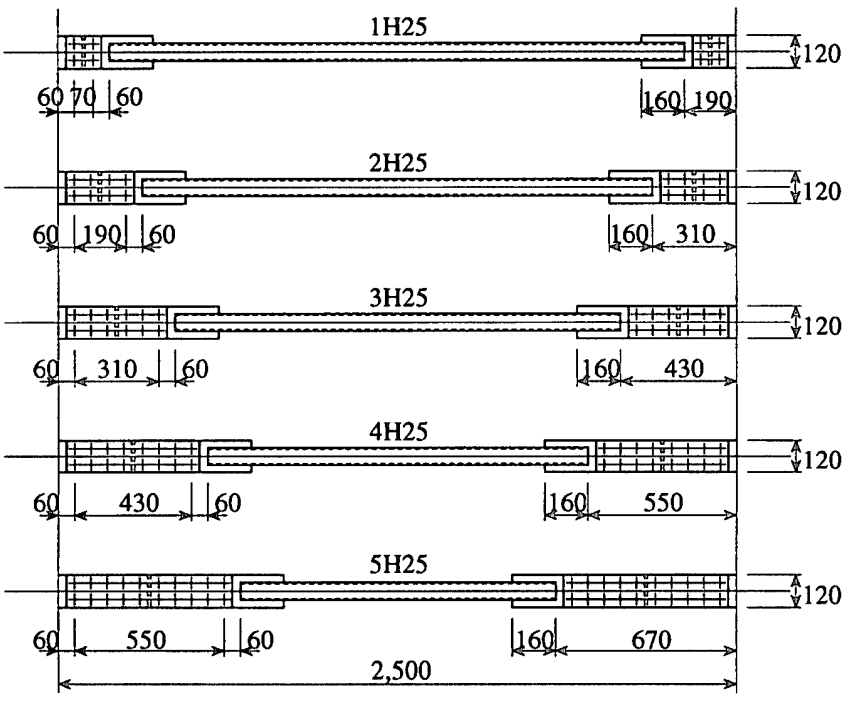

図 14 試験体の形状と寸法

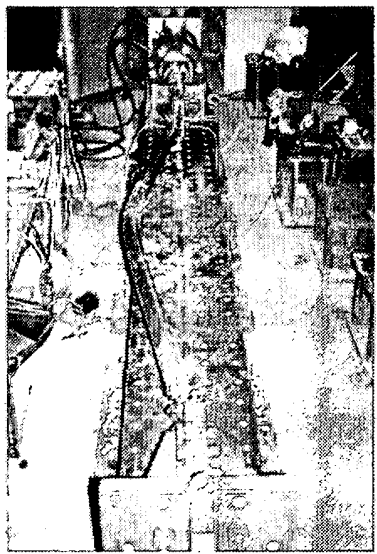

(a) モードA (1H25)

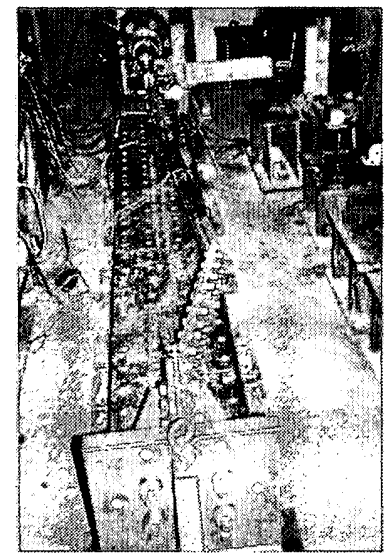

(b) モード B (5H25)
写真 1 座屈変形

A で座屈した $1 \mathrm{H} 25$ 試験体であり，写真 (b) はモードBで座屈した $5 H 25$ 試験体である，写真 (b) で明らかなように，この試験体は手前 側の接合領域だけが面外に屈曲し，他端がほほ真直である。この試 験体では，最大荷重を過ぎてしばらくは図 1 の座屈モード Bに示す ような対称変形が成長したが，その後，手前側接合領域の面外変形 だけが成長し，他方の面外変形は減少した。これは，ガセットプ レートの面外塑性曲げにともなう耐力劣化により，片側にだけ変形 が局所化し，他方が弾性除荷したものと考えられる．他に，最大荷 重に達する以前から片側の接合領域だけが面外に変形するものを多 数確認した。これらは，製作誤差などの影響で応力状態が完全に対 称とはならないため, 応力状態が厳しい方で変形が成長したものと 考えられる。

\section{6。結論}

本論では，管通し平板ガセット形式接合部を有する軸力材を対象 に，座屈モードに対応した簡便な力学モデルを設定し，弾性座屈荷 重を導いた。さらに，各部のプロポーションと座屈モードや座屈荷 重との関係を考察した。一方，ここで提案した弾性座屈荷重算定式 の妥当性は，円形鋼管を用いた座屈実験により検証された。得られ た知見を以下に示す。
表 2 試験体の一覧と諸元

\begin{tabular}{|c|c|c|c|c|c|c|}
\hline 名称 & $\begin{array}{c}\text { ボルト } \\
\text { 列数 }\end{array}$ & $\begin{array}{c}\text { 材長 }(l) \\
(\mathrm{mm})\end{array}$ & $\begin{array}{c}k_{a} l \\
(\mathrm{~mm})\end{array}$ & $\begin{array}{c}k_{a} k_{b} l \\
(\mathrm{~mm})\end{array}$ & $k_{a}$ & $k_{b}$ \\
\hline $1 \mathrm{H} 25$ & 1 & 2,500 & 190 & 60 & 0.076 & 0.316 \\
\hline $2 \mathrm{H} 25$ & 2 & $"$ & 310 & $" 1$ & 0.124 & 0.194 \\
\hline $3 \mathrm{H} 25$ & 3 & $"$ & 430 & $" 1$ & 0.172 & 0.140 \\
\hline $4 \mathrm{H} 25$ & 4 & $"$ & 550 & " & 0.220 & 0.109 \\
\hline $5 \mathrm{H} 25$ & 5 & " & 670 & " & 0.268 & 0.090 \\
\hline
\end{tabular}

表 3 断面寸法と降伏応力度

\begin{tabular}{|c|c|c|c|c|}
\hline \multirow{2}{*}{ 部 位 } & $\begin{array}{c}\text { 断 } \\
\text { 材 面 }\end{array}$ & \multicolumn{2}{|c|}{ 実測值 $(\mathrm{mm})$} & 降伏応力度 \\
\cline { 3 - 4 } & 直径 & 厚さ & $\left(\mathrm{tf} / \mathrm{cm}^{2}\right)$ \\
\hline 軸 部 & $\begin{array}{c}65 \phi \times 5.0 \\
\text { STKM13A }\end{array}$ & 65.0 & 4.93 & 3.30 \\
\hline ガセット板 & $\begin{array}{c}\text { PL-9 } \\
\text { SM400 }\end{array}$ & - & 8.85 & 3.58 \\
\hline 添 板 & $\begin{array}{c}\text { PL-6 } \\
\text { SM400 }\end{array}$ & - & 5.79 & 3.66 \\
\hline
\end{tabular}

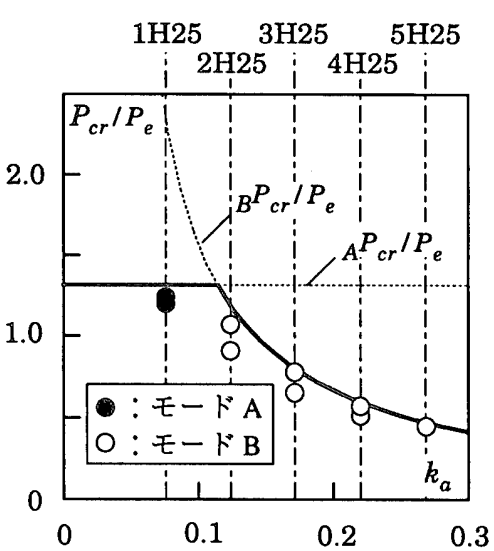

図 15 弾性座屈荷重の実験結果と解析結果

(1) 端部の接合部領域の長さと部材長との比 $\left(k_{a}\right)$ が $0.05 \sim 0.15$ 程 度以下であれば，部材全体が湾曲する座屈モード A が発生し，それ を超えれば接合部領域だけが部分的に屈曲する座屈モード B が発生 する。

（2） $k_{a}$ が $0.05 \sim 0.20$ 程度を超えれば, 座屈荷重が, 両端ピンの 鋼管のオイラー座屈荷重を下回る.

（3）SN400では $k_{a} l / t_{g s}<36$ 程度, SN490では $k_{a} l / t_{g s}<30$ 程 度であれば，モード B の弾性座屈よりもガセットプレート断面が先 に降伏する。

（4）ここで提案した簡便な力学モデルによる座屈荷重の算定結果 は, 実験結果を若干過大評価する。

（5）過大評価の程度は, 座屈モード A・B の境界領域付近で大き w.

（6）座屈モード B で座屈し始めたものは，最終的に，片側接合部 領域の面外屈曲だけが成長する非対称形になる.

\section{参考文献}

1) S. P. Timoshenko and J. M. Gere : Theory of Elastic Stability, second edition, McGraw-Hill, chapter2

2) 駕尾健三, 黒羽啓明, 妹尾与利治, 東郷 武: 鋼管割り込みガ 
セットプレート継手の研究, 日本建築学会論文報告集, 第 90 号, pp.19-24, 1963 年 9 月

3) 三井宜之, 黒羽啓明, 遠藤克彦: 管通しガセットプレート継手 の耐力と変形能力に関する実験的研究, 構造工学論文集, Vol.31 B, 1985 年 4 月

4) 五十嵐定義, 松本竹二, 辻岡静雄, 渡辺律夫 : 鋼管十字形割込 みガセットプレート継手の引張耐力に関する実験的研究, 日本 建築学会構造系論文報告集, 第 372 号, pp.86-92, 1987 年 2 月

5）鈴木敏郎, 小河利行, 佐藤亘宏, 深沢 隆: 塔状卜ラス骨組の 座屈耐力に関する研究（その 2 端部がせん断ボルト接合され る斜材で座屈する場合），日本建築学会構造系論文報告集, 第 434 号, pp.125-135, 1992 年 4 月

6) 多田元英 : 応力制限機構を挿入した 2 層立体トラスの載荷能力 に関する研究, 日本建築学会構造系論文報告集, 第 433 号, pp.103-112, 1992 年 3 月

\section{謝辞}

本研究の一部は, 平成 8 年度文部省科学研究費補助金（総合研究 A）および平成 8 年度鋼材俱楽部・建築鋼構造研究助成金の補助を 受けておこなった。ここに記して謝意を表します。

付録 1 ガセットプレート部・添板部の断面二次モーメントの鋼管 に対する標準的な比率

ここでは，ガセットプレート部・添板部の断面二次モーメントの 鋼管の断面二次モーメントに対する標準的な值を考察する.ただ し，ガセットプレートは全長にわたって同一幅とし，添板幅とガ セットプレート幅は等しいものとする.

各部の寸法を表す主な記号を図 A1 に示す，各部位の標準的なプ ロポーションを規定する係数として以下の記号を定義する.

$$
\begin{aligned}
& \alpha_{t b}=d_{t b} / t_{t b} \quad \text { (鋼管の径厚比) } \\
& \bar{b}_{g s}=b_{g s} / d_{t b} \\
& { }_{e f} \bar{b}_{g s}={ }_{e f} b_{g s} / d_{t b}
\end{aligned}
$$

ただし， $d_{t b}$ は鋼管の直径， $t_{t b}$ は鋼管の管厚， $b_{g s}$ はガセットプ レートの幅, ef $b_{g s}$ はボルト孔欠損を除いたガセットプレートの有効 幅である。

鋼管の管厚が管径に対して十分に小さいとすれば，鋼管の断面積 $A_{t b}$ と断面二次モーメント $I_{t b}$ は次式で与えられる.

$$
A_{t b}=\frac{\pi d_{t b}{ }^{2}}{\alpha_{t b}}, I_{t b}=\frac{\pi d_{t b}{ }^{4}}{8 \alpha_{t b}}
$$

ガセットプレート断面の応力度と鋼管断面の応力度が等しくなる ように断面が決定されているとすれば，ガセットプレートのボルト 孔欠損を除いた有効断面積と鋼管の断面積とを等値することによ り，ガセットプレートの板厚 $t_{g s}$ が次式で与えられる.

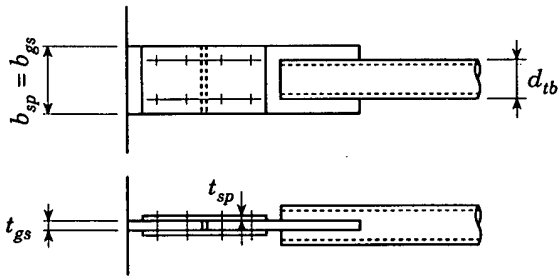

図A1管通しガセット接合部の標準詳細図

$$
t_{g s}=\frac{\pi d_{t b}}{\alpha_{t b} \bar{b}_{g s}}
$$

さらに, ガセットプレートの断面二次モーメント $I_{g s}$ は次のように 与えられる。

$$
I_{g s}=\frac{b_{g s} t_{g s}{ }^{3}}{12}=\frac{\pi^{3} \bar{b}_{g s} d_{t b}{ }^{4}}{12 \alpha_{t b}{ }^{3} \bar{b}_{g s}{ }^{3}}
$$

(A5) と (A7) 式を比較して, $\bar{I}_{g s}=I_{g s} / I_{t b}$ が次のように得られる.

$$
\bar{I}_{g s}=I_{g s} / I_{t b}=\frac{2 \pi^{2} \bar{b}_{g s}}{3 \alpha_{t b}{ }^{2}{ }_{e f} \bar{b}_{g s}{ }^{3}}
$$

一方, 添板の 2 枚合わせた断面積がガセットプレートの断面積に 等しいとすれば, 1 枚の添板厚 $t_{s p}$ はガセットプレート厚の半分と なる.すなわち、

$$
t_{s p}=t_{g s} / 2
$$

添板とガセットプレートとのずれ変形が無視できるほど小さいとす れば, 添板部の曲げ剛性は次式の断面二次モーメント $I_{s p}$ で評価で きる。

$$
I_{s p}=b_{g s}\left(t_{g s}+2 t_{s p}\right)^{3} / 12
$$

(A10)に (A9) 式を代入して次式を得る。

$$
I_{s p}=2 b_{g s} t_{g s}{ }^{3} / 3
$$

(A7) と (A11) 式より $I_{s p}$ は $I_{g s}$ の 8 倍となっており, $\bar{I}_{s p}=I_{s p} / I_{t b}$ が $(\mathrm{A} 8)$ 式を元にして次のように与えられる.

$$
\bar{I}_{s p}=I_{s p} / I_{t b}=\frac{16 \pi^{2} \bar{b}_{g s}}{3 \alpha_{t b}{ }^{2}{ }_{e f} \bar{b}_{g s}{ }^{3}}
$$

JIS に規定された円形鋼管の径厚比を最小自乗近似して求めた值 6) として $\alpha_{t b}=33.22$ を採用し， $\bar{b}_{g s}=1.2,{ }_{e f} \bar{b}_{g s}=1.0$ と仮定すれ ば, (A8), (A12) 式より $\bar{I}_{g s}=0.007, \bar{I}_{s p}=0.06$ が標準的な值とし て得られる。

\section{注1）}

微小変位の仮定の下に (37) 式が得られているが, これを仮定せず に (35) 式のP- $\theta$ 関係をそのまま図示したものが注図1である， $\theta$ がゼロの近傍では，(37) 式で与えられる ${ }_{B} P_{c r} に P$ は一致し，P- $\theta$ 関係の勾配がゼロになっている.この時点で系は不安定挙動を示す が, $\theta$ が増すにつれて $P$ も増加するため, 有限変位領域において 系は再び安定挙動を示す。これらの傾向は，有限変位を扱ったエラ スティカリの座屈たわみ曲線（軸力ー横たわみ関係）にも見られ る.

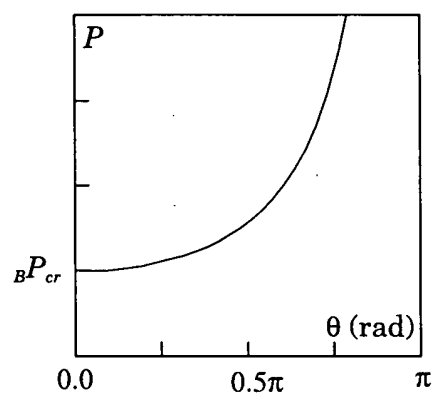

注図 1 軸力一回転角関係

(1997年 7 月 4 日原稿受理，1997年 9 月 5 日採用決定) 